\title{
Spatial Analysis of Determinants of Filariasis-Endemic Areas in West Sumatra
}

\section{Analisis Spasial Faktor Determinan Area Endemik Filariasis di Sumatra Barat}

\author{
Masrizal*, Fivi Melva Diana**, Rosfita Rasyid***
}

\begin{abstract}
*Department of Epidemiology and Biostatistics, Faculty of Public Health, Andalas University, Padang, Indonesia, **Department of Nutrition, Faculty of Public Health, Andalas University, Padang, Indonesia, ***Faculty of Medicine, Andalas University, Padang, Indonesia
\end{abstract}

\begin{abstract}
West Pasaman District and Agam District are filariasis-endemic areas in West Sumatra with prevalence of 12.40 per 100,000 cases and 11.27 per 100,000 cases respectively. This study aimed to determine risk factors associated with the prevalence of filariasis and mapping the vulnerability of the area in West Sumatra. A case control study design was conducted in the West Pasaman District and Agam District. The study used a sample of 74 cases and 74 controls taken by simple random sampling for the case and purposive random sampling for control. Data analysis used univariate, bivariate, multivariate and spatial. The results in Agam District showed that variables associated relation with filariasis ( $p$ value $<0.05$ ) were the level of knowledge, plantations, the paddy, the ceiling of the house. The most dominant risk factor was knowledge. Type of vector that was found was Culex. While in West Pasaman District, the variable associated with filariasis ( $p$ value $<0.05$ ) was the use of mosquito nets, the habit of dressing, marshes, and ceiling. The most dominant risk factor was the ceiling of the house.
\end{abstract}

Keywords: Filariasis, geographic information system, risk, vulnerabilities

\begin{abstract}
Abstrak
Kabupaten Pasaman Barat dan Kabupaten Agam adalah daerah endemis filariasis di Sumatra Barat dengan prevalensi masing-masing 12,40 per 100.000 kasus dan 11,27 per 100.000 kasus. Penelitian ini bertujuan untuk mengetahui faktor risiko yang terkait dengan prevalensi filariasis dan pemetaan kerentanan daerah di Sumatra Barat. Desain studi kasus kontrol dilakukan di Pasaman Barat dan Agam. Penelitian ini menggunakan sampel dari 74 kasus dan 74 kontrol, diambil secara simple random sampling untuk kasus dan purposive random sampling untuk kontrol. Analisis data menggunakan univariat, bivariat, multivariat dan spasial. Hasil penelitian di Kabupaten Agam menunjukkan bahwa variabel yang berhubungan dengan filariasis (nilai $p<0,05)$ adalah tingkat pengetahuan, perkebunan, padi, plafon rumah. Faktor risiko yang paling dominan adalah pengetahuan. Jenis vektor yang ditemukan adalah Culex. Sedangkan di Kabupaten Pasaman Barat, variabel hubungan dengan filariasis (nilai $p<0,05$ ) adalah penggunaan kelambu, kebiasaan berpakaian, rawa-rawa, plafon rumah. Faktor risiko yang paling dominan adalah plafon rumah.
\end{abstract}

Kata kunci: Filariasis, geographic information system, risiko, kerentanan

How to Cite: Masrizal, Diana FM, Rasyid R. Spatial anlysis of determinants of filariasis-endemic areas in West Sumatra. Kesmas: National Public Health Journal. 2017; 12 (2): 79-86. (doi:10.21109/kesmas.v12i2.1300)
Correspondence: Masrizal, Dep. of Epidemiology and Biostatistics, Faculty of Public Health, Andalas University, Perintis Kemerdekaan Street No.94, Padang, Indonesia, Phone: +62751-38613, E-mail: masrizal_khaidir@yahoo.com Received: December $6^{\text {th }} 2016$

Revised: April 26 th 2017

Accepted: September $6^{\text {th }} 2017$ 


\section{Introduction}

Filariasis has become a global public health problem in accordance with the resolution of the World Health Assembly (WHA) in 1997. Filariasis elimination program in Indonesia starts in 2002. To achieve elimination, two pillars are set to be implemented in Indonesia that are cutting off the transmission by prevention with filariasis mass drug administration in endemic areas, and preventing and limiting disabilities due to filariasis. ${ }^{1}$

Indonesia is a filariasis-endemic country. Filariasis spread across Indonesia, especially eastern Indonesia which have a higher prevalence. From year to year, several provinces report the increase in filariasis cases. The number of filariasis cases in 2000 was 6,233 cases, but it highly increased in 2009 as many as 11,914 cases. While the numbers of filariasis incidence in Indonesia in 2010, 2011, 2012 were 11,969, 12,066 and 11,903 cases respectively. ${ }^{2}$

Distribution of the spread of filariasis cases in Indonesia covers almost all provinces, including West Sumatra Province. West Sumatra Province is a filariasisendemic area that ranked the eleventh highest filariasis cases in 2013 with the number of 225 cases spreading across many districts and cities. Of districts and cities in West Sumatra, West Pasaman District and Agam District have high prevalence of 12.40 per 100,000 and 11.27 per 100,000 respectively. ${ }^{3}$

West Pasaman District is a filariasis-endemic area which has 49 filariasis cases with the highest prevalence of filariasis in West Sumatra that is 12.40 in 2014 and followed by Agam district that is 11.27.3

West Pasaman District declared as filariasis-endemic area in West Sumatra since the finding of chronic filariasis patients containing microfilariae in the blood tests clinically finger. People with filariasis distribution were found in five subdistricts of West Pasaman District, such as Kinali Subdistrict, Okanagan Melintang Subdistrict, Pasisia Sasak Subdistrict, Sei. Aur Subdistrict and Batahan Subdistrict. The population of West Pasaman in 2013 is as many as 395,098 inhabitants spreading across 11 districts with the environment of mountains, beaches, swamps, plantations and rice fields. Most of the residents livelihoods are agriculture, farming, fishing, and trade. There are several habits of the population, such as watching television together outside the house, sitting in the stalls along the night. 4

Based on the report by Agam District Health Office in 2014, there were 58 cases of filariasis in Agam district District. The case was spread across seven districts, namely the Tanjung Mutiara Subdistrict (34 persons), Lubuk Basung Subdistrict (12 persons), IV Nagari Subdistrict (6 persons), Palembayan Subdistrict (1 person), Malalak Subdistrict (1 person), Palupuh Subdistrict (1 person), and Tilkam Subdistrict (3 persons). ${ }^{4}$
There are some people's behaviors there, such as some local decision makers have not realized the economic losses due to filariasis and not prioritized activities of mass intervention. The notion of some people that the disease is caused by curse, so they do not need to be treated by health workers but people turn to shamans; lack of community participation in the examination and blood sampling at night; side effects of intervention that the community does not want to continue intervention completely; lack of community participation in preventing filariasis, for example by avoiding themselves from mosquito bites, eliminating mosquito breeding places and going to the health care if any signs of filariasis; the distance where people living far from the clinic so it requires people to come to the clinic by transportation with a quite expensive cost. ${ }^{3}$

There are many risk factors that could cause filariasis. These factors may come from host (host/human), agent (filaria worms) and the environment (environment). One of the trigger factors derived from hosts is individual habits in maintaining animal reservoir which mediates the spread of filariasis and the habit of going out of the house at night. Environmental factors are also the risk factor for the work and activities of individuals that cannot be separated from their interaction with the surrounding environment. The environment is around individuals both inside and outside the home of individuals, such as physical environment inside and outside the home and surrounding biological environment in individual homes. The physical environment including the use of wire netting, temperature, presence of swamps, ponds, rice fields, and bushes. Biological environment consists of the existence of aquatic plants such as water hyacinth and the existence of predator animals that are enemies namely mosquitoes, tilapia fish, catfish, fish heads and tin. ${ }^{2}$

Mapping the distribution of the disease epidemiologically is important, especially mapping the spread of infectious diseases. Using spatial analysis is not only to determine the pattern of disease distribution, high-risk areas and risk factors in terms of area, but to find the cause or source of disease transmission, so that efforts to control the disease and the termination of the chain can be done properly. However, unfortunately, filariasis study with study spatial analysis has not been done, especially in Indonesia. Distribution of the existence of the location and the patterns of spread of filariasis in West Sumatra Province was not known certainly, therefore authors are interested to conduct further study by using spatial analysis (Geographic Information System/GIS) on risk factors of filariasis in West Sumatra Province. ${ }^{5}$

The purpose of this study was to determine the risk factors associated with the prevalence of filariasis and implement the use of GIS for mapping the vulnerability 
of the area in West Sumatra Province.

\section{Method}

The study design was case control study. The study location of study is in West Pasaman District and Agam Districts. The population in this study was patients with filariasis and positive microfilaria in the blood of a finger based on examination results and clinical symptoms of the data of Padang City Health Office. This study used a sample of 74 cases (Agam district with 36 cases and West Pasaman District with 38 cases) and 74 controls (Agam District with 36 controls and West Pasaman District with 38 controls) with a total of 148 samples, matched by age and sex. This study applied simple random sampling technique for the case and purposive random sampling for control. Data analysis used were univariate, bivariate, and multivariate analysis of the vulnerability of the area with spatial.

\section{Results}

Based on the results in Agam District, relation between filariasis and the level of knowledge obtained $\mathrm{p}$ value $=0.004(\mathrm{OR}=4.25,95 \% \mathrm{CI}: 1.43-12.63)$, plantations with $\mathrm{p}$ value $=0,002(\mathrm{OR}=4.00,95 \% \mathrm{CI}: 1.50$ $10.65)$, paddy with p value $=0.003(\mathrm{OR}=4.25,95 \% \mathrm{CI}$ : 1.59-11.31), and the ceiling of the house with $\mathrm{p}$ value $=$ $0.001(\mathrm{OR}=4.75,95 \% \mathrm{CI}: 1.62-13.96)$. The most dominant risk factor was knowledge with $\mathrm{p}$ value $=0.001(\mathrm{OR}$ 8.74 95\% CI: 2.24-34.03).

The study results in West Pasaman District showed the use of mosquito nets with $\mathrm{p}$ value $=0.033(\mathrm{OR}=$ 2.667, 95\% CI: 1.04-6.81), the habit of dressing with $\mathrm{p}$ value $=0.019(\mathrm{OR}=3,5,95 \% \mathrm{CI}: 1.15-10.63)$, marshes with $p$ value $=0.003(\mathrm{OR}=11.0095 \% \mathrm{CI}: 1.42$ 85.20 ), and the ceiling of the house with $p$ value $=0.035$ $(\mathrm{OR}=3.67,95 \% \mathrm{CI}: 1.02-13.14)$. The most dominant risk factor was home ceiling with $\mathrm{p}$ value $=0.021(\mathrm{OR}=$ 5.12, 95\% CI: 1.27-20.47).

\section{Discussion}

Study in Agam District found a significant association between level of education and the prevalence of filariasis in Agam District ( $\mathrm{p}$ value $=0.013$ ). The statistical calculation of $4: 52$ obtained odds ratio (95\% CI $1: 17$ 21:08). It can be concluded that the respondents with low education levels were at risk of infection with filariasis 4:52 times than respondents with higher levels of education. The level of education was a risk factor for the prevalence of filariasis in Agam District.

Results of interviews on the ground prove that most respondents were elderly, and if traced, these respondents did not complete primary school and some of them never went to school (36.11\%) due to geographical and environmental factors, economic constraints, and the inequal development of schools in each area, so the distance between a residence with a school is so far away. In accordance with the concept of health education stating that education is also a learning process at the individual, group or community of those who do not know about the health values become aware, who are not able to over-

Table 1. Distribution of Frequency in Agam District

\begin{tabular}{|c|c|c|c|c|c|c|c|}
\hline \multirow{2}{*}{ Variable } & \multirow{2}{*}{ Category } & \multicolumn{2}{|c|}{ Case } & \multicolumn{2}{|c|}{ Control } & \multicolumn{2}{|c|}{ Total } \\
\hline & & f & $\%$ & f & $\%$ & f & $\%$ \\
\hline \multicolumn{8}{|l|}{ Socioeconomic factors } \\
\hline \multirow[t]{2}{*}{ Education } & Low & 29 & 78 & 25 & 67 & 54 & 74 \\
\hline & High & 7 & 22 & 11 & 33 & 18 & 26 \\
\hline \multirow[t]{2}{*}{ Knowledge } & Low & 30 & 83.33 & 27 & 75 & 57 & 79.17 \\
\hline & High & 6 & 16.67 & 9 & 25 & 15 & 20.83 \\
\hline \multicolumn{8}{|l|}{ Community behavioral factors } \\
\hline \multirow[t]{2}{*}{ The habit of going out at night } & Yes & 28 & 77.78 & 27 & 75 & 55 & 76.39 \\
\hline & No & 8 & 22.22 & 9 & 25 & 17 & 23.61 \\
\hline \multirow[t]{2}{*}{ The use of mosquito nets } & Not use & 21 & 58.33 & 19 & 52.78 & 40 & 55.56 \\
\hline & Use & 15 & 41.67 & 17 & 47.22 & 32 & 44.44 \\
\hline \multirow[t]{2}{*}{ The use of mosquito repellent } & Not use & 21 & 58.33 & 20 & 55.56 & 41 & 56.94 \\
\hline & Use & 15 & 41.67 & 16 & 44.44 & 31 & 43.06 \\
\hline \multirow[t]{2}{*}{ The maintenance of animal reservoir } & Yes & 27 & 75 & 25 & 69.44 & 52 & 72.22 \\
\hline & No & 9 & 25 & 11 & 30.56 & 20 & 27.78 \\
\hline \multicolumn{8}{|l|}{ Environmental factors } \\
\hline \multirow[t]{2}{*}{ The rice fields } & $\leq 500$ meter & 14 & 38.89 & 16 & 44.44 & 30 & 41.67 \\
\hline & $>500$ meter & 22 & 61.11 & 20 & 55.56 & 42 & 58.33 \\
\hline \multirow[t]{2}{*}{ The rivers } & $\leq 500$ meter & 28 & 77.78 & 14 & 38.89 & 42 & 58.33 \\
\hline & $>500$ meter & 8 & 22.22 & 22 & 61.11 & 30 & 41.67 \\
\hline \multirow[t]{2}{*}{ The plantation } & $\leq 500$ meter & 26 & 72.22 & 5 & 13.89 & 31 & 43.06 \\
\hline & $>500$ meter & 10 & 27.78 & 31 & 86.11 & 41 & 56.94 \\
\hline \multirow[t]{2}{*}{ The beach } & $\leq 500$ meter & 12 & 33.33 & 8 & 22.22 & 20 & 27.78 \\
\hline & $>500$ meter & 24 & 66.67 & 28 & 77.78 & 62 & 72.22 \\
\hline
\end{tabular}


Tabel 2. Distribution of Frequency in West Sumatra

\begin{tabular}{|c|c|c|c|c|c|c|c|}
\hline \multirow{2}{*}{ Variable } & \multirow{2}{*}{ Category } & \multicolumn{2}{|c|}{ Case } & \multicolumn{2}{|c|}{ Control } & \multicolumn{2}{|c|}{ Total } \\
\hline & & f & $\%$ & f & $\%$ & f & $\%$ \\
\hline \multicolumn{8}{|l|}{ Socioeconomic factors } \\
\hline \multirow[t]{2}{*}{ Education } & Low & 37 & 97.37 & 35 & 92.11 & 72 & 94.74 \\
\hline & High & 1 & 2.63 & 3 & 7.89 & 4 & 5.26 \\
\hline \multirow[t]{2}{*}{ Knowledge } & Low & 20 & 52.63 & 19 & 50.00 & 39 & 51.32 \\
\hline & High & 18 & 47.37 & 19 & 50.00 & 37 & $48.68 \mathrm{~b}$ \\
\hline \multicolumn{8}{|l|}{ Community behavioral factors } \\
\hline \multirow[t]{2}{*}{ The habit of going out at night } & Yes & 30 & 78.95 & 30 & 78.95 & 60 & 78.95 \\
\hline & No & 8 & 21.05 & 8 & 21.05 & 16 & 21.05 \\
\hline \multirow[t]{2}{*}{ The use of mosquito nets } & Not use & 27 & 71.05 & 17 & 44.74 & 44 & 57.89 \\
\hline & Use & 11 & 28.95 & 21 & 55.26 & 32 & 42.11 \\
\hline \multirow[t]{2}{*}{ The use of mosquito repellent } & Not use & 13 & 34.21 & 12 & 31.58 & 25 & 32.89 \\
\hline & Use & 25 & 65.79 & 26 & 68.42 & 51 & 67.11 \\
\hline \multirow[t]{2}{*}{ The maintenance of animal reservoir } & Yes & 21 & 55.26 & 19 & 50.00 & 40 & 52.63 \\
\hline & No & 17 & 44.74 & 19 & 50.00 & 36 & 47.37 \\
\hline \multicolumn{8}{|l|}{ Environmental factors } \\
\hline \multirow[t]{2}{*}{ The rice fields } & $\leq 500$ meter & 10 & 26.32 & 9 & 23.68 & 19 & 25.00 \\
\hline & $>500$ meter & 28 & 73.68 & 29 & 76.32 & 57 & 75.00 \\
\hline \multirow[t]{2}{*}{ The rivers } & $\leq 500$ meter & 26 & 68.42 & 25 & 65.79 & 51 & 67.11 \\
\hline & $>500$ meter & 12 & 31.58 & 13 & 34.21 & 25 & 32.89 \\
\hline \multirow[t]{2}{*}{ The plantation } & $\leq 500$ meter & 22 & 57.89 & 20 & 52.63 & 42 & 55.26 \\
\hline & $>500$ meter & 16 & 42.11 & 18 & 47.37 & 34 & 44.74 \\
\hline \multirow[t]{2}{*}{ The beach } & $\leq 500$ meter & 8 & 21.05 & 7 & 18.42 & 15 & 19.74 \\
\hline & $>500$ meter & 30 & 78.95 & 31 & 81.58 & 61 & 80.26 \\
\hline
\end{tabular}

Table 3. Statistical Test Results of Bivariate Analysis

\begin{tabular}{|c|c|c|c|c|c|}
\hline Variable & Category & Agam & West Pasaman & Agam & West Pasaman \\
\hline \multirow[t]{2}{*}{ Socioeconomic factors } & Education & 4.52 & 3 & $1.17-21.08$ & $0.31-28.48$ \\
\hline & Knowledge & 4.14 & 1.09 & $1.30-13.94$ & $0.48-2.47$ \\
\hline \multirow[t]{2}{*}{ Community behavioral factors } & The habits of going out at night & 3.75 & 1.00 & $1.24-11.62$ & $0.33-3.11$ \\
\hline & The maintenance of animal reservoir & 3.57 & 1.18 & $1.22-10.66$ & $0.53-2,64$ \\
\hline \multirow[t]{4}{*}{ Environmental factors } & The rice fields & 0.21 & 2.00 & $0.07-0.65$ & $0.18-22.06$ \\
\hline & The rivers & 1.13 & 1.33 & $0.39-3.26$ & $0.30-5.96$ \\
\hline & The plantation & 19.46 & 3.00 & $4.51-112.71$ & $0.31-28.84$ \\
\hline & The beach & - & 2.00 & $3.92-18.35$ & $0.18-22.05$ \\
\hline
\end{tabular}

come their health problems become capable, etc. The level of a person's education will influence the type of work and health behaviors for preventive action against the transmission of filariasis.

Results of statistical analysis to the variable level of knowledge acquired $p$ value $=0.007$, which means there was a significant relation between the level of knowledge and the prevalence of filariasis in Agam District. Statistical test results found the value of $4: 14$ odds ratio (95\% CI: 1.30 - 13.94), thus it can be concluded that respondents with a low level of knowledge were at risk of infection with filariasis 4:14 times than respondents with higher level of knowledge. The level of knowledge is a risk factor of filariasis prevalence in Agam District.

Ardias et $a l,{ }^{5}$ found different results where there was no significant relation between the level of knowledge and the prevalence of filariasis in Sambas District, while Uloli, ${ }^{6}$ found a significant relation between the levels of knowledge and the prevalence of filariasis in Bone Bolango District. Filariasis transmission are linked to socio-cultural aspects, including knowledge, beliefs, attitudes, and habits of the people.

Knowledge is the result of knowing what happens after someone did sensing to a particular object. Sensing occurs through human senses the senses of sight, hearing, smell, taste, and touch. However, most of the dominant sensory functions are the eyes and ears, or cognitive domain knowledge is very important in shaping a person's actions and behavior. Thus the knowledge of someone will affect on their behavior in daily life. ${ }^{7}$

The results of statistical tests found that the level of knowledge in West Pasaman District obtained $p$ value > 
0.05 ( $\mathrm{p}$ value $=0.084)$, which means there was no significant relation between knowledge and the prevalence of filariasis in West Pasaman District. This is not in accordance with the results obtained in Agam District stating that there was a significant relation between the levels of knowledge and the prevalence of filariasis.

It was observed during the study that a lack of knowledge of respondents did not escape from the low education level of respondents who generally were elderly. Despite having low level of knowledge, respondent were not infected by filariasis because influenced by environmental factors or other measures, such as using wire/netting and their home away from marshes. This resulted in no significant correlation between the levels of knowledge and the prevalence of filariasis premises.

The results of interviews with respondents showed that respondents who had a low level of knowledge about the disease filariasis do not know, how it is transmitted, causes, clinical symptoms, prevention and intervention of the disease filariasis. Information about filariasis rarely received by the public through print and electronic media or health worker. Knowledge of the vectors of filariasis is very important as supporting the successful efforts of the transmission chain termination and eradication of filariasis. ${ }^{8}$

Statistical test results for the behavior of respondents going out at night note that there was a significant relation between the habit of respondents going out at night with the prevalence of filariasis in Agam District ( $p$ value $=0.008$ ). By the unknown value odds ratio of 3.75 (95\% CI 1:24 - 11.62), it can be concluded that the respondents with the habit of going out at night the risk of infection with filariasis 3.75 times compared to respondents who did not have a habit of going out at night. Habit of going out at night there was a risk factor for the prevalence of filariasis in Agam District. Habits of respondents to go out of the house at night will increase the risk of prevalence of filariasis where the same time mosquitoes are also active search for prey. Based on biting time, it is known that some types of mosquitoes such as Anopheles, Culex $s p$ and Mansonia sp has biting activity in the early evening, after sunset until sunrise, except for Aedes $s p$ that have a habit of biting (biting behavior) at noon.

This is in accordance with the conditions of the people in the field which mostly have jobs as farmers, oil palm plantation workers and fishermen who require long night. The habit to be outside the home until late night, in which the vectors are exophillic and exophagic, will make it easier to get mosquito bites. 6,9

The results showed that the majority of respondents in both groups together have habit of going out at night, which was a tradition in the community. This resulted in no significant correlation between such habit with the prevalence of filariasis.

The use of mosquito nets while sleeping is one of the preventive measures to prevent contact with mosquitoes that have a habit of biting or sucking the blood in the house (Endophagik). The impact of some diseases that are transmitted through mosquito vectors such as filariasis, malaria, and dengue hemorrhagic fever (DHF) can be minimized through the use of mosquito nets while sleeping so it can reduce the prevalence/morbidity. ${ }^{8}$ Study in Agam District found that no significant relation exists between the habit of wearing a mosquito net and the prevalence of filariasis in Agam District ( $\mathrm{p}$ value $=$ $0.781)$.

Results of the study found by Nasrin, 10 that there is no significant relation between the habits of wearing a mosquito net with the prevalence of filariasis ( $p$ value $>$ 0.05 ). Behavior or habits of respondents did not use mosquito nets while sleeping due to various reasons such as feeling sick (hot) and not practical. Besides, the behavior of habit occurred due to economic reasons in which the poor cannot afford to buy insecticide-treated mosquito nets. Meanwhile, local governments and related agencies have not run a program to provide insecticide-treated nets, especially for people in endemic areas with low economic class. Insecticide-treated nets (long-lasting insecticide nets) is a mosquito net that has been coated with anti-mosquito netting by the manufacturer. Mosquito nets are not harmful to human health because of the anti-mosquito nets attached cannot poison people. Insecticide-treated nets aim to protect the public, especially infants, toddlers and pregnant women are particularly vulnerable to diseases resulting from mosquito bites transmitters. 10

Results of statistical test bed nets in West Pasaman District obtained $p$ value $<0.05$ ( $p$ value $=0.033$ ), meaning that there was a significant association between the use of mosquito nets bedtime with the prevalence of filariasis. The use of mosquito nets is an attempt to prevent contact with mosquitoes. Mosquito net of any type that is used by the respondent at the time of sleep remain an important effort in order to prevent transmission of disease filariasis, but the use of mosquito nets would be meaningless if it is not followed by the regular use by a person.

The use of mosquito repellent is one safeguard to avoid mosquito bites. Anti-mosquito chemical is used to repel mosquitoes (repellent) as a topical medication anti-mosquito and kills mosquitoes as mosquito coils, electric and spray. The use of mosquito repellent in the morning and evening can prevent mosquito bites as filariasis vectors. Based on the statistical test, there was no significant relation between the habit of using anti-mosquito with the prevalence of filariasis in Agam District ( $\mathrm{p}$ value $=0.147)$ odds ratio of 12.49 (95\% CI: 0.17-1.43). 
Statistical test results in West Pasaman District also obtained $\mathrm{p}$ value $>0.05$ ( $\mathrm{p}$ value $=0.808)$, which means there was no significant relation between the habit of using mosquito repellent with the prevalence of filariasis. Thus it can be concluded that the respondents who had a habit of using mosquito repellent were infected by filariasis 0.49 times riskier than respondents who did not have the habit of using mosquito repellent. Study conducted by Nasrin, 10 found different results where there was a significant correlation between the habit of using repellent and the prevalence of filariasis ( $\mathrm{p}$ value $<0.05$ ).

In general, respondents had already used mosquito repellent, but keep in mind the level of resistance of the mosquito vector-borne diseases such as filariasis. In addition to the habits of the people with frequent activity at night, the use of mosquito would be useless because the chances of getting mosquito bites remain.

The statistical test found that there was a significant relation between the habit of keeping animal reservoir with the prevalence of filariasis in Agam District ( $p$ value $=0.009)$ and the value of 3.57 odds ratio $(95 \%$ CI: 1.22 - 10.66). Thus it can be concluded that the respondents who had a habit of keeping animals at risk of infection reservoir filariasis were 3.57 times than respondents who did not have the habit of keeping animals reservoir. Keeping an animal reservoir habits is risk factor for the prevalence of filariasis in Agam district District. This is because the people living around the plantation area have a habit of keeping cats and dogs as pets to keep plantations from pests such as wild pigs and rats. Thus the pets are likely to already get infected with filariasis because they often get in contact with mosquitoes and can be suspected as an animal reservoir for transmission of filariasis. Uloli states that the custom cats had a significant relation to the occurrence of filariasis while study by Son expressed a different result. ${ }^{9}$

The existence of breeding place (mosquito breeding places) such as rice fields, rivers, and coastal plantation is a cause of transmission of filariasis for the environment as it is very suitable for living place of mosquitoes. Statistical test results found that there was a significant correlation between the presence of the field and the prevalence of filariasis in Agam District ( $\mathrm{p}$ value = 0.002 ). From the statistical calculation obtained odds ratio of $12: 21$ (95\% CI $0.7-0.65)$, it can be concluded that the respondents living near the fields ( $\leq 200$ meters) had risk of infection with filariasis 0:21 times than respondents not living near the fields. The existence of the fields near ( $\leq 200$ meters) where the respondent live was a protective factor for the prevalence of filariasis in Agam District. Maryen, ${ }^{11}$ states that the residential neighborhood within $\leq 200$ meters from the fields signi-ficantly related to the prevalence of filariasis in Manokwari ( $\mathrm{p}$ value $=0.004)$. Variables with plantations obtained $p$ value $=0.000$ which means there was a significant correlation between the existence of plantations with the prevalence of filariasis in Agam District. Based on the results of statistical tests found value odds ratio of 19:46 (95\% CI: 4:51 - 112.71), thus it can be concluded that the respondents living near the source $(\leq 200$ meters) risk of infection with filariasis 19:46 times than respondents not li-ving close to plantation. Similar results were found by Sulistiowati with plantations as mosquitobreeding sites in the prevalence of malaria. ${ }^{12}$

The results of statistical tests in West Pasaman District obtained of $p$ value $>0.05(p$ value $=0.375)$, meaning that there is no significant correlation between the presence of gardens $\leq 500$ meters with the prevalence of filariasis. Most gardens cultivated by people in the study area are forest in the hills around the house residents. These conditions should lead to a high potential for contact between mosquitoes as vectors of filariasis with the community, but this is not entirely the case study areas.

Based on observations, most gardens are oil palm plantation belonging to a company that is always cleaned, so that mosquitoes are not so much resting and breeding in the garden. People who have house near the botanic garden also use wire netting while sleeping. This resulted in no significant correlation between the existence of plantations and the prevalence of filariasis.

The existence of garden near ( $\leq 200$ meters) to the residence of respondents was the risk factor for the prevalence of filariasis in Agam District. Most cases of filariasis were in the neighborhood palm oil, since it relates to the respondents working as farmers and oil palm plantation workers that are managed by private parties. So that, people who reside in the oil palm plantations in the transmission of filariasis, especially vulnerable people with a habit to be outside the home until late night, in which the vectors are exophillic and exophagic, will easily get a mosquito bites.

Variable in which the beach obtained $\mathrm{p}$ value $<0.05$ means that there was a significant correlation between the presence of the beach and the prevalence of filariasis in Agam District. Based on the results of statistical tests, odds ratio cannot be found for the control group, nothing was close to the beach, so there was no comparison between the case group and control group to get a high risk.

Statistical test results obtained $p$ value $>0.05$ ( $p$ value $=0.625$ ), meaning that there was no significant correlation between the presence of shore $\leq 500$ meters and the prevalence of filariasis in West Pasaman District. Residents who used to work as fishermen chose to build house near the beach. During the study, there were many people who had residence close to the beach, but not infected by filariasis as influenced by environmental factors 
or other measures, such as using chicken wire and their home away from marshes. This resulted in no significant correlation between the presence of the beach and the prevalence of filariasis. ${ }^{13}$

Based on conditional logistic regression analysis, the variables that have a major influence ( $p$ value $<0.05$ ) in the prevalence of filariasis in Agam District was existence of plantations ( $\mathrm{p}$ value $<0.05, \mathrm{OR}=19: 46$ ). Variables with plantations in the final multivariate model obtained $\mathrm{p}$ value $<0.05, \mathrm{OR}=19: 46$ and regression coefficient $=$ 2.97. This means that the statistic showed that there was a significant association between the presence of plantations and the prevalence of filariasis in Agam District. Thus it can be concluded that the respondents living near the source ( $\leq 200$ meters) had risk of infection with filariasis 19:46 times than respondents who did not live near the source.

Multivariate analysis in West Pasaman District found a significant independent variable contributing to the prevalence of filariasis, namely ceiling of the house with $\mathrm{p}$ value of 0.021 . The statistical test calculations obtained OR $=5.12(95 \%$ CI: $1.279-20.470)$. This means that respondents who did not have the ceiling of the house would be at risk of filariasis by 5.12 times compared to respondents who had the ceiling of the house. Thus the most dominant factor at risk to the prevalence of filariasis in West Pasaman District in 2014 was ceiling of the house.

Geographic Information System can help in determining the level of vulnerability of the region and identify the clustering of filariasis incidence. Determination of the vulnerability zone filariasis aims to identify areas of high risk and do intervene proactively on risk factors, such as the environmental and behavioral interventions. This is pursued through a strategy-based communicable disease control area by eliminating a source of transmission of the disease and the treatment of those already infected. $5,14,15$

The vulnerability zone information was obtained from the use of GIS to map the land use overlay techniques and topographic maps of Agam District. Overlay of spatial yield information about zones or areas that have vulnerabilities among which Districts of Tanjung Mutiara, Lubuk Cone, IV Nagari, Palembayan, Palupuh, Baso and IV Koto. Thus the areas that has the vulnerability are expected to get more attention from the parties involved in efforts to control and terminate of the chain of transmission of filariasis.

Spatially in West Pasaman District, it is known that the distribution of filariasis prevalence contained in 9 out of 11 districts. The spread of filariasis prevalence was generally found in the river, in the bush, plantations, swamps. Most artifacts showed the spread of filariasis in Sungai Aur.
Risk factors of filariasis in Agam District was the level of knowledge, while in West Pasaman District was the use ceiling of the house. Grouping (clustering) of filariasis prevalence in Agam District was in areas of SubangSubang and Muaro Putuih, and grouping of cases that was in area of Sungai Aur, namely Nagari Nagari Air Haji and Binjai, as well as parts of the Valley Crossing.

\section{Conclusion}

The dominant risk factor of filarias incidence in Agam District is the level of knowledge, while in West Pasaman District it is the use of the house ceiling. Grouping (clustering) of filariasis incidence in Agam District is in areas of Subang-Subang and Muaro Putuih, and grouping of cases is in the area of Sungai Aur, namely Nagari Air Haji and Binjai, as well as parts of the Valley Crossing. Education about filariasis vector control program and an integrated environment need to be implemented and improved.

\section{References}

1. Kementrian Kesehatan Republik Indonesia. Filariasis di Indonesia. Buletin Jendela Epidemiologi. 2010; 1 (Juli): 1-24.

2. Kementrian Kesehatan Republik Indonesia. Profil pengendalian penyakit dan penyehatan Lingkungan. Jakarta: Kementrian Kesehatan Republik Indonesia; 2015.

3. Dinas Kesehatan Provinsi Sumatra Barat. Data filariasis. Sumatra Barat: Dinas Kesehatan Provinsi Sumatra Barat; 2014.

4. Dinas Kesehatan Kabupaten Agam. Laporan program filariasis. Lubuk Basung: Dinas Kesehatan Kabupaten Agam; 2013.

5. Ardias SO. Faktor lingkungan dan perilaku masyarakat yang berhubungan dengan kejadian filariasis di kabupaten sambas. Jurnal Kesehatan Lingkungan Indonesia. 2012; 11 (2): 199-207.

6. Uloli R. Analisis faktor-faktor risiko kejadian filariasis di kabupaten Bone Bolango Provinsi Gorontalo. Yogyakarta: Universitas Gadjah Mada; 2007.

7. Notoatmodjo S. Pengantar pendidikan kesehatan dan ilmu perilaku kesehatan. Jakarta: Rineka Cipta; 2003.

8. Salim MF. Penggunaan sistem informasi geografis untuk pemetaan kerentanan wilayah berdasarkan faktor risiko kejadian filariasis di Kabupaten Agam. Yogyakarta: Universitas Gadjah Mada; 2015.

9. Babba I, Hadisaputro S, Sawandi S. Faktor-faktor risiko yang mempengaruhi kejadian malaria (studi kasus di wilayah kerja puskesmas hamadi Kota Jayapura). 2006; 1- 11.

10. Nasrin. Faktor lingkungan dan perilaku yang berkaitan dengan kejadian filariasis di Kabupaten Bangka Barat. Semarang: Universitas Diponegoro; 2008.

11. Maryen Y. Faktor risiko yang berhubungan dengan kejadian filariasis di Kabupaten Manokwari Provinsi Papua Barat. Yogyakarta: Universitas Gadjah Mada; 2014.

12. Sulistiowati ZD. Analisis spasial kejadian malaria di kecamatan Sosoh Buay rayap Kabupaten Ogan Komering Ulu. Yogyakarta: Universitas Gadjah Mada; 2011.

13. Ngwira BMM, Tambala P, Perez AM, Bowie C, Molyneux DH. The geo- 
graphical distribution of lymphatic filariasis infection in Malawi. Filaria Journal. 2007; 7: 1-7.

14. Achmadi UF. Manajemen penyakit berbasis wilayah. Jakarta: Raja Grafindo Persada; 2012. 01-153.

15. Upadhyayula SM. A cohort study of lymphatic filariasis on socio eco- nomic conditions in Andhra Pradesh. India. plos one journal. 2012; 7: 3.

16. Ikhwan. Faktor lingkungan, perilaku dan kejadian filariasis di kabupaten Bintan, Kepulauan Riau. Kesmas: National Public Health Journal. 2016; (1): 39-45. 